Bangladesh Journal of Anatomy January 2013, Vol. 11 No. 1 pp 30-33

\title{
Comparison of the Foot Height, Length, Breadth and Types between Santhals and Bangalees of Pirganj, Rangpur
}

\author{
Sultan Ahmed ${ }^{1}$, Afruza Bulbul Akhter ${ }^{2}$, Selina Anwar ${ }^{3}$, Anjum Ara Begum ${ }^{4}$, Khalilur Rahman ${ }^{5}$, \\ Narayan Chandra Saha ${ }^{6}$
}

\begin{abstract}
Context: The structural and functional components of the foot are composed of highly refined interrelated segments which provide a stable base for supporting the body in both load support and shock absorption during standing, running, walking and jumping. The study was aimed to measure the foot of adult Santhal males of Pirganj upazilla, Rangpur to find out to racial characteristics of their own and compare with Bangalee adult males of the same area.

Materials and Methods: The study was carried out on 60 (sixty) adult male Santhals and 120 (one hundred and twenty) adult male Bangalees. Foot length, foot breadth and foot height was measured. Foot index was calculated and foot shape was determined.

Results: Height, length and breadth of foot were higher in Bangalees than Santhals and showed a significantly higher value for the foot length. Regarding the foot shape, slender foot was found more in Bangalees but most of these two groups have standard foot shape.

Conclusion: In the present study significantly higher value of foot length and higher percentage of slender foot in Bangalees but higher percentage of broad foot among the Santhals were found. Slender foot in Bangalees may be due to less weight bearing habit than Santhals.
\end{abstract}

Key word: Foot, Santhals, Bangalees

\section{Introduction}

Estimation of dimensions of different body segments has been proved to be extremely useful to anatomists, anthropologists and forensic scientists. An important determination for a functional and comfortable foot support is how well the planter foot shape is. The foot shapes are corresponding to different weight bearing conditions ${ }^{1}$. Both the foot length and foot width were found to be increased

1. Associate Professor, Department of Anatomy, Rangpur Medical College, Rangpur

2. Professor, Department of Anatomy, Rangpur Community Medical College, Rangpur

3. Professor, Department of Anatomy, Rangpur Medical College, Rangpur

4. Professor, Department of Anatomy, Prime Medical College, Rangpur

5. Associate Professor, Department of Anatomy, Shaheed Ziaur Rahman Medical College, Bogra

6. Assistant Professor, Department of Anatomy, Satkhira Medical College, Satkhira

Correspondence: Dr. Sultan Ahmed during weight bearing. The shapes of human feet are changed due to their habits and presence of disease. In addition the deviation from normal pattern of walking often due to trauma or disease affects the locomotors system and cause imbalance of pressure on the foot, which may cause injury to the foot or other parts of the body.

Several studies elsewhere have investigated the anthropometric characteristics of foot of adults of different ethnic groups ${ }^{2,3,4,5}$. Information is scarce on the anthropometric characteristics of various tribal population of Bangladesh. Santhals are one of the largest tribal communities in Bangladesh. They live in greater district of Rangpur, Dinajpur and Rajshahi. Total population of Santhals in Bangladesh is about 2, 26,000 and in Chatra union of Pirganj Upazilla their total number is about $8000^{6}$. There is no available data about the foot shape of Bangalee and Santhals. So the study was aimed at to the 
anthropometric measurements of foot of adult Bangalee and Santhal males and to find out any racial characteristics of their own.

\section{Variables studied:}

- To measure the height, length and breadth of foot and look for any differences in foot height, foot length and foot breadth between Banglalees and Santhals.

- To find out foot index and to classify different foot shapes.

\section{Methods}

Procedure of Measurements of Foot:

The study was carried out on 60 adult male Santhals and 120 adult male Bangalees.

All the measurements were done according to Perveen ${ }^{7}$. All the measurements were done on the right lower limb according to Jung².

Height was measured from the most prominent point of medial malleolus of the tibia to the sole of the foot along the medial aspect of the leg, with a measuring tape.

Length was measured by a slide caliper with the subject in a relaxed sitting position. The ankle should be perpendicular to the foot. It was measured from an imaginary vertical line drawn from the posterior prominence of the heel, to the tip of the longest toe, on the planter aspect of the foot. In some people, the first toe is the longest, in other people; the second toe is the longest ${ }^{3}$.

Breadth was measured between the medial prominence of the first metataso-phalangeal (MTP) joint and the lateral prominence of the fifth MTP joint of the foot. The person kept the foot on the floor and measured on the planter aspect of the foot by slide caliper.

Shape was determined by calculation of foot index. Foot index was calculated for each subject by dividing the foot length by the foot breadth $\times 100$. The mean foot index and SD were calculated and three types of foot shape were determined according to the foot index (Manna et al. 2001).

$$
\begin{array}{ccc}
\text { Slender type } & : & \mathrm{FI}^{*}<-\mathrm{SD} \\
\text { Standard type } & : & \mathrm{Fl}-\mathrm{SD}<\mathrm{F}^{*}<+\mathrm{SD} \\
\text { Broad type } & : & \mathrm{Fl}>\mathrm{FI}+\mathrm{SD} \\
\left(\mathrm{FI}^{*}=\text { Individual foot index, } \mathrm{FI}=\right. & \text { Mean foot index, }
\end{array}
$$$$
\mathrm{SD}=\text { Standard deviation) }
$$

\section{Results}

Height, length, breadth and index of the foot

The mean foot height was $7.1 \pm 1.1 \mathrm{~cm}$ for the Bangalee subjects and that of Santhals was 7.0 \pm 1.1 $\mathrm{cm}$ (Table-I). But the mean difference was not statistically significant ( $p>0.05)$, though the mean height was a little bit higher among the Bangalees than the Santhals. But a statistically significant $(p<0.05)$ mean difference was found between Bangalees $(25.1 \pm 1.2 \mathrm{~cm})$ and Santhals $(24.6 \pm 1.4$ $\mathrm{cm}$ ) in terms of foot length indicating the foot length was higher among the Bangalees than the Santhals. On the contrary, no statistically significant $(p>0.05)$ mean difference of foot breadth was found between Bangalees $(9.3 \pm 0.7 \mathrm{~cm})$ and Santhals $(9.2 \pm 0.7 \mathrm{~cm})$. However, data shows that the foot breadth was higher among the Bangalees than the Santhals.

The foot index of the subjects was calculated based on foot length and foot breadth (table I). The mean foot index for the Bangalees was $2.7 \pm 0.17$ and for the Santhals was $2.68 \pm 0.23$. The mean foot index was a little bit higher among Bangalees but mean

\begin{tabular}{|c|c|c|c|}
\hline \multirow{2}{*}{$\begin{array}{l}\text { Variables }(\mathrm{cm}) \\
\text { of the foot }\end{array}$} & \multicolumn{2}{|c|}{ Subjects } & \multirow{2}{*}{$\begin{array}{c}\mathrm{p} \\
\text { value }\end{array}$} \\
\hline & $\begin{array}{c}\text { Bangalees } \\
(n=120)\end{array}$ & $\begin{array}{c}\text { Santhals } \\
(n=60)\end{array}$ & \\
\hline Height & $\begin{array}{c}7.1 \pm 1.1 \\
(4.9-11.0)\end{array}$ & $\begin{array}{c}7.0 \pm 1.1 \\
(5.0-11.0)\end{array}$ & 0.677 \\
\hline Length & $\begin{array}{c}25.1 \pm 1.2 \\
(22.1-27.5)\end{array}$ & $\begin{array}{l}(24.6 \pm 1.4) \\
(20.0-28.0)\end{array}$ & 0.021 \\
\hline Breadth & $\begin{array}{c}9.3 \pm 0.7 \\
(7.5-11.0)\end{array}$ & $\begin{array}{c}9.2 \pm 0.7 \\
(6.6-10.8)\end{array}$ & 0.280 \\
\hline Index & $\begin{array}{c}2.70 \pm 0.17 \\
(2.27-3.30)\end{array}$ & $\begin{array}{c}2.68 \pm 0.23 \\
(2.26-3.50)\end{array}$ & 0.689 \\
\hline
\end{tabular}
difference was not statistically significant.

\section{Table-I}

Distribution of the subjects by foot measurements

$p$ value reached from unpaired t test

Results are shown as ranges and mean \pm SDs.

Foot shapes:

Table-II and figure 1 showed that proportion of standard foot was higher among Santhals $(80 \%)$ than that of Bangalees $(75 \%)$ whereas the slender foot was higher among Bangalees $(14.16 \%$ vs 
$8.33 \%)$. Broad foot shape was more or less same among Bangalees (10.83\%) and Santhals (11.66\%).

Table-II

Distribution of the subjects by shapes of the foot

\begin{tabular}{lcccc}
\hline Foot shape & \multicolumn{5}{c}{ Subjects } \\
$\begin{array}{l}\text { according to } \\
\text { Foot index }\end{array}$ & $\begin{array}{c}\text { Bongalees }(\mathrm{n}=120) \\
\text { No. }\end{array}$ & $\%$ & \multicolumn{2}{c}{ Santhals $(\mathrm{n}=60)$} \\
\hline $\begin{array}{l}\text { Slender } \\
\text { (mean-1SD) }\end{array}$ & 17 & 14.16 & 5 & 8.33 \\
$\begin{array}{l}\text { Standard } \\
\text { (Mean } \pm 1 S D)\end{array}$ & 90 & 75 & 48 & 80 \\
$\begin{array}{l}\text { Broad } \\
\text { (Mean + 1SD) }\end{array}$ & 13 & 10.83 & 7 & 11.66 \\
\hline
\end{tabular}

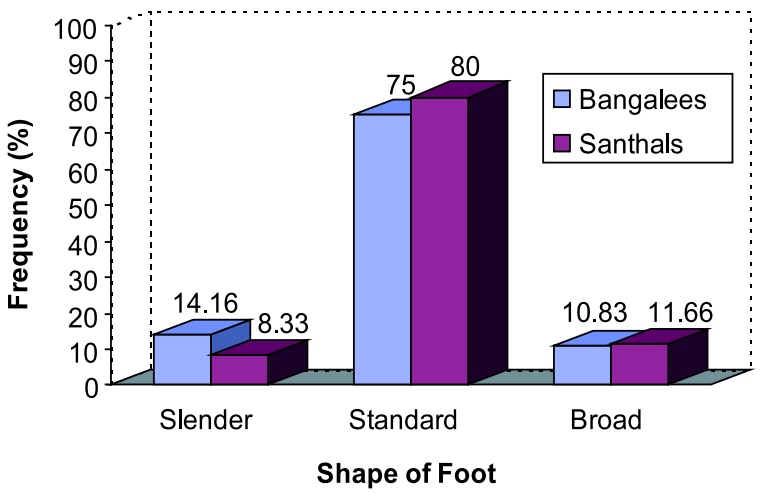

Fig.-1: Bar diagram showing the distribution of foot shapes in Bangalees and Santhals.

\section{Discussion}

The human body contains 206 bones, approximately $1 / 10^{\text {th }}$ of which are confined to the foot. Each foot is a highly complex structure with 26 major bones, 32 synovial joints and 112 ligaments plus two sesamoid bones encased in a tendon under the heads of the first metatarsal bones ${ }^{1}$.

In the present study the mean of foot height, foot length and foot breadth were higher in Bangalees than Santhals and reaches a significantly high level regarding the foot length $(p<0.021)$.

Sanli et $\mathrm{al}^{4}$ worked on 80 Turkey subjects and reported that the mean foot length were $26.25 \mathrm{~cm}$. Bhavna and Nath ${ }^{5}$ worked on 503 Indian populations in Delhi and reported that the mean foot length was
$24.88 \mathrm{~cm}$. Tsung et al ${ }^{1}$ worked on Hong Kong and found that mean foot length was $24.3 \mathrm{~cm}$. The present study showed that the mean foot length was less than that of Turkish and Indian population but higher than Gujarat medical students and Hong Kong peoples.

Again Tsung et al ${ }^{1}$ found that mean foot breadth was $9.7 \mathrm{~cm}$. Manna et al ${ }^{3}$ worked on 100 subjects from Medenipur district West Bengal (India) and found that their mean foot breadth was $8.55 \mathrm{~cm}$. The mean foot breadths of Bangalees and Santhals have similarity with the mean foot breadth of West Bengal, the Punjabi, Chinese and Turkish. But the mean foot breadths of Nigerian subjects have a little bit higher than of Bangalees and Santhals.

Foot shape was categorized according to foot index. In the present study the mean foot index were $2.70 \pm 0.17 \mathrm{~cm}$ and $2.68 \pm 0.23 \mathrm{~cm}$ among Banglalees and Sathals respectively. The mean foot index was a little bit higher among the Bangalees, but the mean difference was not statistically significant $(p>0.05)$. The data showed that the proportion of slender foot was higher among the Bangalees $(14.16 \%)$ than the Santhals $(8.33 \%)$ whereas standard and broad foot were higher among the Santhals $(80 \%$ \& $11.66 \%)$ than the Bangalees $(75 \%$ \& $10.83 \%)$ respectively (table II, fig 1). The higher percentage of slender foot in Bangalees and broad foot in Santhals may be due to more weight bearing functions among the Santhals.

\section{References:}

1. Tsung BUS, Zhang M, Fan YB, Boone AD. Quantitative comparison of planter foot shapes under different weight bearing conditions. JRRD, Hong Kong, China 2003: 527-26.

2. Jung S, Lee S, Boo J, Park J. Classification of foot types for designing footwear of the Korean elderly. $5^{\text {th }}$ Symposium. On footwear biomechanics, Zurich, Switzerland 2001: 48-49.

3. Manna I, Pradhan D, Ghosh S, Kar SK, and Dhara, P. A comparative study of foot dimensions between adult male and female 
and evolution of food hazards due to using of footwear, Journal of Physiological Anthropology and Applied Human Science 2001; 20(4): 421-46.

4. Sanli SG, Kizilkanat ED, Boyan N, Ozsahin ET, Bozkir MG, Soames R, et al. Stature estimation based on hand length and foot length, Cukurova University, Faculty of Medicine, Department of Anatomy, Adana, Turky 2005; 18: 589-96.

5. Bhavna and Nath S. Use of lower limb measurement reconstructing stature among Shia Muslims. The International Journal of Biologic Anthropology ${ }^{\mathrm{TM}}$ ISSN: 1939-459. Date of access 24/11/2009.
6. Jasuja OP. Estimation of stature from hand phalange length. Journal of Indian Association of Forensic Medicine 2004; 26(3): 100-106.

7. Pervin Akhter. An anthropometric study of lower limb segment lengths measurements and their relationship with the stature and measurements of ultrasonographic fetal variables and their relationship with the maternal stature and determination of somatotype, foot shape of Bangladeshi adult Muslim females (thesis) Dhaka, University of Dhaka 2006

8. Patel SM, Shah GV, Patel SV. Estimation of height from measurements of foot length in Gujrat Region. India Journal of the Anatomical Society 2007; 56(1): 2121-25. 